\title{
The Comparison of 25-Hydroxyvitamin D3 between Patients With and Without Cervical Cancer
}

Dodi Suardi $^{1 *(D)}$, Feny Renita ${ }^{1}$, Andi Kurniadi ${ }^{1}$, Akhmad Yogi Pramatirta ${ }^{1}$ (D), Raden Tina Dewi Judistiani ${ }^{2}$ (D), Yudi Mulyana Hidayat ${ }^{1}$, Budi Setiabudiawan ${ }^{3}$

${ }^{1}$ Department of Obstetrics and Gynecology, Faculty of Medicine, Universitas Padjadjaran, Dr. Hasan Sadikin General Hospital, Bandung, Indonesia; 'Department of Public Health, Faculty of Medicine, Universitas Padjadjaran, Bandung, Indonesia; ${ }^{3}$ Department of Pediatric, Faculty of Medicine, Universitas Padjadjaran, Dr. Hasan Sadikin General Hospital, Bandung, Indonesia

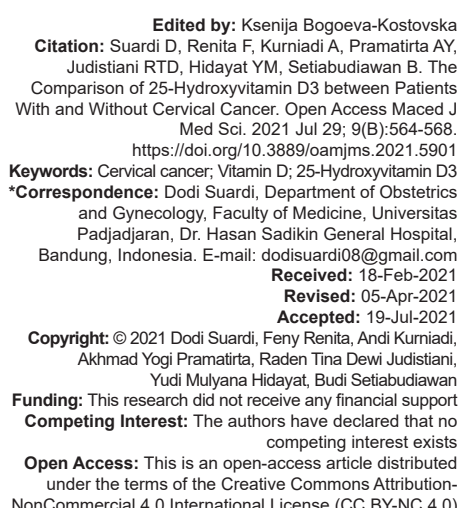

Edited by: Ksenija Bogoeva-Kostovsk Edited by: Ksenija Bogoeva-Kostovska
Citation: Suardi D, Renita F, Kurniadi A, Pramatirta AY, Judistiani RTD Renita F, Kurniadi A, Pramatirta AY, Comparison of 25-Hydroxyvitamin D3 between Patients With and Without Cervical Cancer. Open Access Maced Med Sci. 2021 Jul $29 ; 9$ (B) :564-568. Med Sci. 2021 Jul 29; 9(B):564-568
https://doi.org/10.3889/oamjms.2021.5901 Keywords: Cervical cancer; Vitamin D; 25-Hydroxyvitamin D3 *Correspondence: Dodi Suardi, Department of Obstetrics and Gynecology, Faculty of Medicine, Universitas Padjadjaran, Dr. Hasan Sadikin General Hospital, Bandung, Indonesia. E-mail: dodisuardi08@gmail.com Received: 18-Feb-202 Accepted: $19-\mathrm{Jul}-2021$ Copyright: ๑ 2021 Dodi Suardi, Feny Renita, Andi Kurniadi, Akhmad Yogi Pramatirta, Raden Tina, Dewi Judistiani, Yudi Mulyana Hidayat, Budi Setiabudiawan Funding: This research did not receive any financial support Competing Interest: The authors have declared that no competing interest exists pen Access: This is an open-access article distributed under the terms of the Creative Commons Attribution-

\section{Abstract}

BACKGROUND: Vitamin D was currently believed to have effects on numerous cancer pathogenic processes.

AIM: This study was to assess the correlation of Vitamin D serum level in women with carcinoma cervix and also evaluate the effect of carcinoma cervix on the Vitamin D serum.

METHODS: This was an observational with a cross-sectional study. Participants were women with cervical cancer who have not received any treatment, presented to the Oncology Clinic of the Obstetrics and Gynecology Department of Dr. Hasan Sadikin General Hospital, and women without cervical cancer. The level of Vitamin D3 was analyzed in the Serology Laboratory of Clinical Pathology Department of Dr. Hasan Sadikin General Hospital.

RESULTS: There were 113 participants consisted of 58 women with cervical cancer and 55 healthy women. Mean levels of Vitamin D3 were significantly lower in cervical cancer group than non-cervical cancer group (26.74 \pm 13.166 vs. $32.16 \pm 14.86, p=0.022)$.

CONCLUSION: The level of Vitamin D3 was found to be significantly higher in the non-cervical cancer group than cervical cancer group.

\section{Introduction}

Cervical cancer is considered as a global burden due to its high prevalence and mortality. Numerous studies have contributed to better management of cervical cancer patients, however, the prevalence and mortality remain high. This urges the need for better prevention measures, rather than just focusing on patient management [1], [2]. Vitamin D or 25-hydroxyvitamin D3 has been known for its effects on important physiological processes on calcium and phosphate homeostasis, along with bone mineralization and osteogenesis, however, now studies have discovered that Vitamin D also has various extraskeletal effects related to the incidence and prognosis of many diseases including cardiovascular diseases, diabetes, and cancer. Vitamin $\mathrm{D}$ is currently believed to have effects on carcinogenesis, involving inflammation, apoptosis, cell proliferation and differentiation, angiogenesis, cancer invasiveness, and metastasis [3], [4], [5], [6]. Vitamin D increases apoptosis, reduces cell proliferation, and induces the expression of growth inhibitory molecules.

Vitamin $D$ also reduces angiogenesis through molecular processes and reduces cancer invasiveness and metastasis through the regulation of cancer progressivity molecules expressions [4], [7], [8]. This makes the Vitamin D as an important and highly potential substance for cervical cancer's primary and secondary prevention. On top of that, patients with cervical cancer are believed to have a lower level of Vitamin D compared to healthy individuals. However, the data on Vitamin $D$ in relation to cervical cancer are still scarce and inconclusive. Many studies related to Vitamin D to other types of cancer, such as colorectal, prostate, and breast cancer [9], [10], [11]. This study was determined to compare the level of Vitamin D3 between patients with cervical cancer and healthy women.

\section{Methods}

\section{Design}

This observational analytic study with crosssectional design was conducted in the Oncology Clinic of the Obstetrics and Gynecology Department and the 
Serology Laboratory of Clinical Pathology Department in Dr. Hasan Sadikin General Hospital in December 2019-February 2020. This study was approved by the Research Ethics Committee of the Faculty of Medicine, Padjadjaran University/Dr. Hasan Sadikin Hospital (LB.02.01/X.6.5/340/2019). The subjects were separated into two groups (cervical cancer and non-cervical cancer) and then compared the levels of Vitamin $D$ between two groups.

The selection of research subjects begins with determining the population and determining inclusion and exclusion criteria. This study's population was women of reproductive age with a range of 15-49 years who go to the Oncology Polyclinic of Hasan Sadikin Hospital, Bandung. The cervical cancer group was all women with new cases of cervical cancer who met the inclusion and exclusion criteria. Cervical cancer group patients have been diagnosed with cervical biopsy examination and have not started therapy. All research subjects who met the inclusion and exclusion criteria will have a gynecological examination, laboratory examinations (Vitamin D levels), thorax radiology, CT scan, ultrasonography, and MRI serum Vitamin D levels to determine the stage of cervical cancer. The examination of 25-hydroxyvitamin D3 levels was carried out in the clinical serology Laboratory of Clinical Pathology, Hasan Sadikin Hospital, Bandung. The procedure for checking the levels of 25-hydroxyvitamin D3 is by taking 3 cc of venous blood into the tube and leaving it for $30 \mathrm{~min}$. Then, the samples were centrifuged at $3000 \mathrm{rpm}$ for $15 \mathrm{~min}$, separating two aliquots of $0.5-1 \mathrm{~mL}$ each, and store samples at $-20^{\circ} \mathrm{C}$ before examination with the electrochemiluminescence immunoassay method.

\section{Participants and recruitment}

Subjects were recruited by total sampling and selected using inclusion and exclusion criteria. All women with cervical cancer who fit the inclusion and did not fit the exclusion criteria were included into cervical cancer group and women with no cervical cancer who were willing to join the study were included in the non-cervical cancer group. The inclusion criteria for cervical cancer group were women with a new case of primary of cervical cancer, subjects were patients of oncology clinic but had not started therapy yet, subjects were willing to be participants of this study. The inclusion criteria for noncervical cancer group were subject had no other type of cancer, and subjects willing to be participants of this study. The exclusion criteria were women who had chronic diseases, other cancer, or under treatment medication.

The sample size was determined using formula for numerical categorical analysis study sampling formula:

$$
n_{1}=n_{2}=2\left(\frac{Z_{\alpha}+Z_{\beta} S}{X_{1}+X_{2}}\right)^{2}
$$

$$
\begin{gathered}
n_{1}=n_{2}=2\left(\frac{1.96+1.64 \times 1}{1}\right)^{2} \\
\mathrm{n}=2(13.03)=26.03 \approx 27
\end{gathered}
$$

Therefore, the total of minimum sample for this study was 27 subjects each category, then added by $10 \%$ of possible subject exclusion resulting in the minimum sample of $27+2,7=29.7$ each category or around $30+30=60$ subjects.

\section{Variables and measurement}

Independent variable of this study was patients with cervical cancer, normal healthy women (non-cervical cancer). The dependent variable in this study was the level of 25-hydroxyvitamin D3. The confounding variables were age and body mass index (BMI). Level of 25-hydroxy-vitamin D3 was measured by enzyme-linked immunosorbent assay (ELISA) kits in the serology laboratory of clinical pathology department of Dr. Hasan Sadikin General Hospital.

\section{Statistical analysis}

Data of this study were analyzed using SPSS 24.0 for Windows. Bivariate analysis was done using various methods. Normality test was done using Shapiro-Wilk test. Unpaired t-test was done if the data were normally distributed and alternatively MannWhitney U-test if the data were not normally distributed. Categorical data were analyzed using Chi-square or

\begin{tabular}{|c|c|c|c|}
\hline \multirow[t]{3}{*}{ Variable } & \multicolumn{2}{|l|}{ Groups } & \multirow[t]{3}{*}{$\mathrm{p}$-value } \\
\hline & Cervical cancer & Non-cervical cancer & \\
\hline & $\mathrm{n}=58$ & $n=55$ & \\
\hline Age & & & 0.930 \\
\hline Mean \pm SD & $47.07 \pm 7.276$ & $46.00 \pm 5.136$ & \\
\hline Median & 47.00 & 44.00 & \\
\hline Range (min-max) & $30.00-63.00$ & $30.00-56.00$ & \\
\hline Parity & & & 0.07 \\
\hline Nulliparity & $0(0.0 \%)$ & $10(18.2 \%)$ & \\
\hline Primiparity & $9(15.5 \%)$ & $7(12.7 \%)$ & \\
\hline Multiparity & $44(75.9 \%)$ & $36(65.5 \%)$ & \\
\hline Grande multiparity & $5(8.6 \%)$ & $2(3.63 \%)$ & \\
\hline Menarche (year) & & & 0.882 \\
\hline Mean \pm SD & $11.05 \pm 1.330$ & $11.03 \pm 1.104$ & \\
\hline Median & 11.00 & 11.00 & \\
\hline Range (min-max) & $9.00-14.00$ & $8.00-13.00$ & \\
\hline BMI & & & 0.175 \\
\hline Mean \pm SD & $19.72 \pm 4.397$ & $21.22 \pm 3.602$ & \\
\hline Median & 20.7 & 21.2 & \\
\hline Range (min-max) & $10.30-27.4$ & $11.10-33.70$ & \\
\hline Marital status & & & 0.001 \\
\hline Married & $58(100.0 \%)$ & $45(81.8 \%)$ & \\
\hline Not married & $0(0.0 \%)$ & $10(18.2 \%)$ & \\
\hline Age of first sexual intercourse & & & 0.001 \\
\hline Mean \pm SD & $18.06 \pm 2.882$ & $18.29 \pm 9.635$ & \\
\hline Median & 18.00 & 22.00 & \\
\hline Range (min-max) & $13.00-24.00$ & $16-30.00$ & \\
\hline Number of sex partner & & & 0.02 \\
\hline 0 & $0(0.0 \%)$ & $10(18.2 \%)$ & \\
\hline 1 & $51(87.9 \%)$ & $42(76.3 \%)$ & \\
\hline 2 & $7(12.1 \%)$ & $3(5.45 \%)$ & \\
\hline
\end{tabular}
alternatively exact Fisher and Kolmogorov-Smirnov if

Table 1: Subject characteristics 
the conditions for Chi-square were not met. Variables were statistically significant if $p \leq 0.05$.

\section{Results}

The total of participants in this study was 113 , with 58 women in the cervical cancer group and 55 in the non-cervical cancer group. No statistically significant differences were found in age, parity, BMI, and menarche, among the characteristic data between the groups, indicating that both groups were homogenous and feasible to continue the statistical test (Table 1). The $1^{\text {st }}$ age of sexual intercourse $(p=0.001)$, marital status $(p=$ $0.001)$, and the number of sexual partners $(p=0.02)$ were significantly difference between the groups (Table 1). The mean of Vitamin D3 levels was found $26.74 \pm 13.166$ in cervical cancer group and $32.16 \pm 14.866$ in non-cervical cancer group (Table 2). Vitamin D3 was found significantly lower in the cervical cancer women group compared to non-cervical cancer women group $(p=0.22)$.

Table 2: Levels of Vitamin D3 in both groups

\begin{tabular}{|c|c|c|c|}
\hline \multirow[t]{3}{*}{ Variable } & \multicolumn{2}{|l|}{ Groups } & \multirow[t]{3}{*}{$p$-value } \\
\hline & Cervical cancer & Non-cervical cancer & \\
\hline & $\mathrm{n}=58$ & $\mathrm{n}=55$ & \\
\hline Levels of Vitamin D3 & & & 0.022 \\
\hline Mean \pm SD & $26.74 \pm 13.166$ & $32.16 \pm 14.866$ & \\
\hline Median & 23.50 & 27.87 & \\
\hline Range (min-max) & $9.18-75.93$ & $12.65-72.73$ & \\
\hline
\end{tabular}

\section{Discussion}

Human knowledge about the function of Vitamin D has developed in the past 20 years. Vitamin D plays a role in calcium and phosphate hemostasis and bone mineralization, and osteogenesis. At present, Vitamin D shows interesting extraskeletal effects because it is related to the incidence and prognosis of critical medical conditions such as cancer, cardiovascular disease, or diabetes [3], [4], [5], [12], [13], [14], [15], [16].

The levels of Vitamin D3 were found significantly lower in the cervical cancer group compared to non-cervical cancer group. It is related to the one of the theories that Vitamin D and its receptors play a role in the inflammation process. Inflammation in cancer plays a role in the process of angiogenesis, cell growth, invasion, metastasis, response to treatment, and immunity [17]. Vitamin $D$ helps regulation in decreasing NF signaling, one of the essential factors in inflammation [8]. Apoptosis also regulated by Vitamin D and its receptors. In one study, it was proven that mice without Vitamin D receptors (VDR) were found to have delayed apoptosis in the mammary epithelium [18], [19]. A study by Hosono et al. in a population in Japan found that Vitamin D consumption provides a protective effect against invasive cervical carcinoma [14].

Vitamin D3 is metabolized in the liver to 25-hydroxyvitamin-D3 and then metabolized in the kidneys into its active form, 1,25-dihydroxyvitamin-D3 [4]. The end product of the Vitamin $D$ hydroxylation process is calcitriol [21]. The calcitriol arrives at the target cell and binds to the VDR protein. The VDR will then undergo changes that eventually form Vitamin D response elements [22]. In the literature, there has been found an association between Vitamin D and cervical cancer. A study by Friedrich et al. found that the VDR protein was found elevated in cervical cancer [13]. The increased VDR could be due to a decrease in the result of the hydroxylation of Vitamin D. The same study also found that cervical cancer can target Vitamin D analog therapy that may have both therapeutic and preventive effects [13]. VDRs act as nucleus receptors for cells called genomic effects and affect non-nuclei as nongenomic receptors. The VDR is a transcription-dependent ligand factor that belongs to the steroid hormone and thyroid hormone superfamily genes [24].

Vitamin $D$ and its analogs can also reduce the expression of telomerase reverse transcriptase, which is commonly found in cancer cells that contribute to immortal phenotypes in malignant cells [25]. VDRs were able to suppress the transcription of hypoxia inducible factor 1 alpha which encourages the expression of vascular endothelial growth factor, one of the main regulators of angiogenesis. In the same way, Vitamin $D$ can also reduce interlekin-8 through downregulation by $\mathrm{NF}_{k} \beta$ [26]. The results of this study were consistent with the existing theory, thereby Vitamin $\mathrm{D}$ deficiency is considered as one of the factors in the etiology that triggers cervical cancer. This study's limitations were that there was no dietary recall for foods containing Vitamin $D$ and the length of exposure to sunlight. Furthermore, data on the average Vitamin D status in the Indonesian population are minimal, so there is no reference value for 25-hydroxyvitamin D3 levels for the average Indonesian. Researchers also did not compare Vitamin D levels in various types of cervical cancer in the cervical cancer group.

\section{Conclusion}

The level of Vitamin D3 was found to be significantly higher in the non-cervical cancer group than cervical cancer group.

\section{Acknowledgments}

I would like to thank the Head of Department of Obstetrics and Gynecology, Head of Gynecologic 
Oncology Division of the Department of Obstetrics and Gynecology, Dr. Hasan Sadikin Hospital/Faculty of Medicine, Head of Dr. Hasan Sadikin Hospital, Dean of Faculty of Medicine Padjadjaran University, Bandung, and my $\mathrm{PhD}$ advisors during the study.

\section{References}

1. Gonzalez-Martin A, Marth C, Landoni F, McCormack M, Colombo N, Mahner S, et al. Cervical cancer: ESMO clinical practice guidelines for diagnosis, treatment and follow-up. Ann Oncol. 2018;29(4):262. https://doi.org/10.1093/annonc/mdy160 PMid:29741577

2. Andrijono, Purwoto G, Sekarutami SM. Pedoman Pelayanan Klinis Kanker Serviks. Indonesia: Kemenkes RI; 2015. p. 36.

3. Vahedpoor Z, Jamilian M, Bahmani F, Aghadavod E, Karamali M, Kashanian M, et al. Effects of long-term Vitamin D supplementation on regression and metabolic status of cervical intraepithelial neoplasia: A randomized, double-blind, placebocontrolled trial. Horm Cancer. 2017;8(1):58-67. https://doi. org/10.1007/s12672-016-0278-x

PMid:28050798

4. Merchan BB, Morcillo S, Martin-Nunez G, Tinahones FJ, Macias-Gonzalez M. The role of Vitamin D and VDR in carcinogenesis: Through epidemiology and basic sciences. J Steroid Biochem Mol Biol. 2017;167:203-18. https://doi. org/10.1016/j.jsbmb.2016.11.020

PMid:27913313

5. Serrano D, Gnagnarella P, Raimondi S, Gandini S. Metaanalysis on Vitamin $D$ receptor and cancer risk: Focus on the role of Taql, Apal, and Cdx2 polymorphisms. Eur J Cancer Prev. 2016;25(1):85-96. https://doi.org/10.1097/ cej.0000000000000132

PMid:25738688

6. De Haes P, Garmyn M, Degreef H, Vantieghem K, Bouillon R, Segaert S. 1,25-Dihydroxyvitamin D3 inhibits ultraviolet B-induced apoptosis, Jun kinase activation, and interleukin-6 production in primary human keratinocytes. $\mathrm{J}$ Cell Biochem. 2003;89(4):663-73. https://doi.org/10.1002/jcb.10540 PMid:12858333

7. Welsh J. Cellular and molecular effects of Vitamin D on carcinogenesis. Arch Biochem Biophys. 2012;523(1):107-14. PMid:22085499

8. Bao BY, Yao J, Lee YF. 1alpha, 25-dihydroxyvitamin D3 suppresses interleukin-8-mediated prostate cancer cell angiogenesis. Carcinogenesis. 2006;27(9):1883-93. https://doi. org/10.1093/carcin/bgl041

PMid: 16624828

9. Vaughan-Shaw PG, Buijs LF, Blackmur JP, Theodoratou E, Zgaga L, Din FV, et al. The effect of Vitamin D supplementation on survival in patients with colorectal cancer: Systematic review and meta-analysis of randomised controlled trials. Br J Cancer. 2020;123(11):1705-12. https://doi.org/10.1038/ s41416-020-01060-8

PMid:32929196

10. Trump DL, Aragon-Ching JB. Vitamin D in prostate cancer. Asian J Androl. 2018;20(3):244. https://doi.org/10.4103/aja.aja_14_18 PMid:29667615

11. Estébanez N, Gómez-Acebo I, Palazuelos C, Llorca J, Dierssen-Sotos T. Vitamin D exposure and risk of breast cancer: A meta-analysis. Sci Rep. 2018;8(1):1-13. https://doi. org/10.1038/s41598-018-27297-1

12. Agic $A, X u H$, Altgassen $C$, Noack F, Wolfler MM, Diedrich $K$ et al. Relative expression of 1,25-dihydroxyvitamin D3 receptor, Vitamin D 1 alpha-hydroxylase, Vitamin D 24-hydroxylase, and Vitamin D 25-hydroxylase in endometriosis and gynecologic cancers. Reprod Sci. 2007;14(5):486-97. https://doi. org/10.1177/1933719107304565 PMid: 17913968

13. Friedrich $M$, Rafi L, Mitschele T, Tilgen $W$, Schmidt $W$, Reichrath J. Analysis of the Vitamin D system in cervical carcinomas, breast cancer and ovarian cancer. Recent Results Cancer Res. 2003;164:239-46. https://doi. org/10.1007/978-3-642-55580-0_17

PMid:12899526

14. Hosono S, Matsuo K, Kajiyama H, Hirose K, Suzuki T, Kawase T, et al. Association between dietary calcium and vitamin D intake and cervical carcinogenesis among Japanese women. Eur J Clin Nutr. 2010;64(4):400-9. https://doi.org/10.1038/ ejcn.2010.28 PMid:20197786

15. Lappe JM, Travers-Gustafson D, Davies KM, Recker RR Heaney RP. Vitamin D and calcium supplementation reduces cancer risk: Results of a randomized trial. Am J Clin Nutr. 2007;85(6):1586-91. https://doi.org/10.1093/ajcn/85.6.1586 PMid:17556697

16. Mamede AC, Tavares SD, Abrantes AM, Trindade J, Maia JM, Botelho MF. The Role of vitamins in cancer: A review. Nutr Cancer. 2011;63(4):479-94. https://doi.org/10.1080/01635581. 2011.539315

PMid:21541902

17. Colotta F, Allavena P, Sica A, Garlanda C, Mantovani A. Cancerrelated inflammation, the seventh hallmark of cancer: Links to genetic instability. Carcinogenesis. 2009;30(7):1073-81. https:// doi.org/10.1093/carcin/bgp127

PMid: 19468060

18. Narvaez CJ, Matthews D, LaPorta E, Simmons KM, Beaudin S Welsh J. The impact of Vitamin D in breast cancer: Genomics, pathways, metabolism. Front Physiol. 2014;5:213. https://doi. org/10.3389/fphys.2014.00213

PMid:24982636

19. Guzey M, Luo JH, Getzenberg R. Vitamin D3 modulated gene expression patterns in human primary normal and cancer prostate cells. J Cell Biochem. 2004;93(2):271-85. https://doi. org/10.1002/jcb.20182

PMid: 15368355

20. Chung I, Han G, Seshadri M, Gillard BM, Yu WD, Foster BA, et al. Role of Vitamin $D$ receptor in the antiproliferative effects of calcitriol in tumor-derived endothelial cells and tumor angiogenesis in vivo. Cancer Res. 2009;69(3):967-75. https:// doi.org/10.1158/0008-5472.can-08-2307

PMid:19141646

21. Köstner K, Denzer N, Mueller CS, Klein R, Tilgen W, Reichrath J. The relevance of Vitamin D receptor (VDR) gene polymorphisms for cancer: a review of the literature. Anticancer Res. 2009;29(9):3511-36.

PMid:19667145

22. Kishimoto M, Fujiki R, Takezawa S, Sasaki $Y$, Nakamura T, Yamaoka $\mathrm{K}$, et al. Nuclear receptor mediated gene regulation through chromatin remodeling and histone modifications. Endocr J. 2006;53(2):157-72. https://doi.org/10.1507/endocrj.53.157 PMid: 16618973

23. Jensen SS, Madsen MW, Lukas J, Binderup L, Bartek J. Inhibitory effects of $1 \alpha, 25$-dihydroxyvitamin D3 on the G1-S phasecontrolling machinery. Mol Endocrinol. 2001;15(8):1370-80. 
https://doi.org/10.1210/mend.15.8.0673

PMid: 11463860

24. Ben-Shoshan M, Amir S, Dang DT, Dang LH, Weisman Y, Mabjeesh NJ. 1 $\alpha, 25$-dihydroxyvitamin D3 (Calcitriol) inhibits hypoxia-inducible factor-1/vascular endothelial growth factor pathway in human cancer cells. Mol Cancer Ther. 2007;6(4):14339. https://doi.org/10.1158/1535-7163.mct-06-0677

PMid:17431122 